\title{
The French Play: An Ethnodrama About Applied Theatre for Social Justice Education in Middle School
}

\author{
Allison Balabuch \\ University of Victoria
}

Author's Note

Correspondence concerning this article should be sent to allisonbalabuch@gmail.com

\begin{abstract}
In this study, I investigate the use of applied theatre with French Immersion Grade 8 students to better understand social justice issues. Through unstructured interviews, four participants were asked to recall their past experiences participating in applied theatre projects as a learning experience and as a process to better understand social justice issues. Participants' words and feedback were then used to create an ethnodrama script, performed by the participants and me via video conference. Findings are grouped under five categories; Doll's (2013) 4Rs: Richness, Rigor, Recursion, and Relations and Freire's (2000) concept of conscientization. Participants in applied theatre reported they had a space to tell authentic stories in their own words, became more self-confident, and work towards being catalysts for change. The purpose of this article is to inform educators of the possibilities in using applied theatre and problem-posing education for social justice education and to share the process of ethnodrama as a methodology in arts-based research.
\end{abstract} education

Keywords: applied theatre; ethnodrama; problem-posing education; social justice

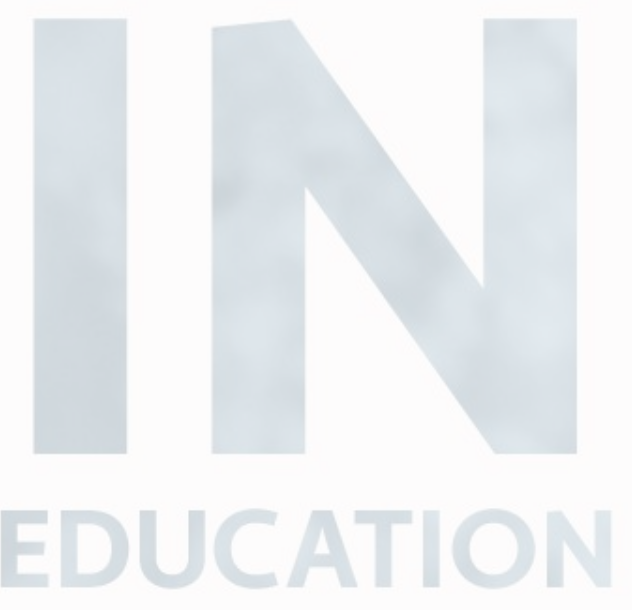




\section{The French Play: An Ethnodrama About Applied Theatre for Social Justice Education in Middle School}

Social justice and multicultural education have become increasingly important in the past few years with ongoing Truth and Reconciliation, the Black Lives Matter movement, and a wider public understanding that systemic racism exists in every corner of the globe. In Canada, "teachers are accustomed to 'teaching about' multiculturalism through activities considered to represent cultural diversity" (Ward, 2017, p. 31), which Ward refers to as the "dance, dress, and diet" (p. 31) approach. What is missing from this approach is a deeper understanding of social justice education and "critical dissonance' (calling into question current school practices)" (p. 31).

As a middle school French-immersion teacher, over the past 6 years, I have been using an applied theatre process with Grade 8 students, which they have nicknamed "The French Play," to explore social justice issues, improve French language production, and to attempt to be a catalyst for change. Applied theatre is a broad term that describes theatre done often in alternative spaces such as prisons, community programs, and schools with a focus on social and political change. Applied theatre is participatory and often includes participants with little to no theatre experience (Belliveau \& Lea, 2011; Conroy et al., 2018; O’Connor \& Anderson, 2015; Taylor, 2002).

Starting from a prompt, either a setting or a time period in history, students in my Grade 8 French Immersion classes worked alone or in small groups, co-wrote French scenes based on their educational research and inquiry, their personal experiences, and/or improvisational work in the group. Those scenes were then workshopped as a large group to modify and interweave them into a united narrative for performance by reading scripts as a group, rewriting, and rewording the texts. Often characters from one scene would be added to other scenes as the students felt their individual characters needed to interact in order to tell a full story. The final script was produced and directed by the students. As they worked toward performance, students continued to negotiate and change the scenes and the staging in a recursive cycle of praxis: reflection and action, all in French. For this study, I wanted to examine what value there is in using an applied theatre approach rather than other "teaching about" approaches to social justice and second language education. The purpose of this article is to inform educators of the possibilities in using applied theatre and problem-posing education for social justice education and to share the process of ethnodrama as a methodology in arts-based research.

The two French Plays written and performed by the participants in this study were Le gobelet d'or (The Golden Goblet) in 2016 and Le tyran (The Bully) in 2018. Le gobelet d'or is a play about a time-travelling archeologist who is attempting to steal the golden goblet. As he travels through time, he learns about slavery, sexism, racism, and social class inequities. By the end of his journey from Ancient Egypt to The Second World War, he learns that human rights are more valuable than gold. Le tyran is a play about a high school bully who is trapped in the school gym over the weekend. He is visited by the ghosts of past bullied students over a 100-year period and learns empathy and kindness. He changes his ways and makes amends for his past behaviour.

\section{Pedagogical Frameworks}

Paolo Freire (2000) talked about the importance of abandoning the banking model of education where teachers seek to, "'fill' the students by making deposits of information which he or she 
considers to constitute true knowledge" (p. 76). In The French Plays, I provided only a prompt. In Le gobelet d'or, the prompt was to set the play anywhere in history between $750 \mathrm{CE}$ and 1800 CE. The prompt for Le tyran was an existing set of a high school gym that we would have access to for the performances. Students worked through a process of co-creation and reflection to create a script for performance to both gain a better understanding of the theme and to share with an audience of their peers in an attempt to be a catalyst for truth and change. This is common in applied theatre genre as, "frequently, applied theatre is constructed as a response to social or political challenges and is seen as a process where difference and change can be wrought through its making" (O'Connor \& O'Connor, 2009, p. 471). The scenes and plays do not come from the teacher's belief or decision about what is important or true but the students' voices. Applied theatre provides this space for true dialogue between teachers and students and the world. The participants in Le gobelet d'or chose to widen the time frame I had given them as they worked to include ancient Greece and Egypt and the Second World War because of their own interests in those time periods. "The teacher cannot think for her students, nor can she impose her thoughts on them. Authentic thinking, thinking that is concerned about reality, does not take place in a tower of isolation" (Freire, 2000, p. 77). Freire's goal is conscientization, which implies that an action is taken beyond simple awareness of the issue. Key here is the idea of authenticity for the student in what is being learned. Students in both plays chose issues that they wanted to investigate, research, and share with an audience of their peers.

Applied theatre connects to the research genre of ethnodrama and ethnotheatre that uses real life events to create a performance piece to engage an audience in the findings of the research (Denzin \& Lincoln, 2018). In research, using ethnodrama as a means of representing findings, the claim is that there is no one universal truth but instead multiple individual truths. Knowledge is therefore subjective, interactive and open to interpretation (Nimmon, 2007). Research data are transformed into scripts using the words of the participants in combination with the words of the researcher and the existing body of knowledge. The scripts my students wrote came from their own educational inquiries and their own lived experiences and knowledge, paralleling the way ethnodrama is used in qualitative research or arts-based research to generate the material from which a script is written and developed (Saldaña, 2003). In essence, this applied theatre approach means the teacher facilitates the students becoming researchers of their own social reality. My goal of encouraging the students to seek knowledge is for it to become a catalyst for conscientization. Throughout the process, each class that participated in The French Play expressed both the excitement of examining their own lives and understandings of the world and working collaboratively through the process of trying to transform the information so that others could share these new understandings.

My research purpose was to find out more about the experience of applied theatre of my former student-participants. I ask the following questions in this study: What was important for the applied theatre process to be successful for the students in their opinion? Has it changed their actions and ways of understanding the world in any way?

\section{Drama as an Educational Tool: Applied Theatre as a Model of Problem-Posing Education}

Paolo Freire (2000) described the difference between a banking concept of education and problem-posing education:

Whereas banking education anesthetizes and inhibits creative power, problem-posing education involves a constant unveiling of reality ... Students, as they are increasingly 
posed with problems relating to themselves in the world and with the world, will feel increasingly challenged and obliged to respond to that challenge ... their response to the challenge evokes new challenges, followed by new understandings, and gradually the students come to regard themselves as committed. (p. 81)

Applied theatre as a pedagogical tool for learning and teaching is an example of problemposing education. Freire (2000) outlined the following requirements for authentic dialogue as necessary components of problem-posing education: critical thinking, humility, faith in humanity, hope, and love. All of these aspects promote a climate of mutual trust. As in ethnodrama as a research methodology, applied theatre is co-created and is driven by the participant/student voices. For these voices to be heard, the criteria for problem-posing education and authentic dialogue must be central components of the process at all stages: script creation, staging, reworking the story, and performing. Boal (1993/1985) posed an important question in his work Theatre of the Oppressed: "Should art educate, inform, organize, influence, incite to action, or should it simply be an object of pleasure?" (p. xiii). Boal's (1993/1985) work outlined a model for forum theatre, a similar participatory theatre approach to applied theatre that is both political and participatory. For applied theatre to be effective and genuine as a pedagogical approach, it must be clear that theatre is being used as an intentional agent of change stemming from our collective needs as teachers, students, and communities (O'Connor \& O'Connor, 2009; Prentki \& Pammenter, 2014).

\section{Ethnodrama}

Throughout human history, theatre and oral storytelling have been used to inspire thought, provoke understanding, evoke an emotional reaction, and create a catalyst for change between performers and their audience. Ethnodrama takes a critical stance that sees reality in praxisresearch and action.

As a methodology, ethnodrama comes from the traditions of ethnography, involving collecting data about the human condition from careful observation and detailed participant stories. Saldaña (2003) indicated that

an ethnodrama, the script, consists of analyzed and dramatized significant selections from interview transcripts, field notes, journal entries, or other written artifacts. Characters in an ethnodrama are generally the research participants portrayed by actors, but the actual researchers and participants themselves may be cast members. (p. 218)

Research is done with a co-constructivist approach in which the participants and researcher build understanding and continually refine and redefine their understandings.

Mienczakowski (2019) describes ethnodrama as theatre that includes live discussion, feedback, and interaction between the researcher, audience, participants and/or the actors with the goals of social and cultural change (p. 3). Ethnodrama can be written with the intention of production on the stage or as an alternative to a traditional academic paper. Malhotra and Hotton (2018) included reader reflection questions in their script as academic paper to engage the reader/audience to participate in the shared experience of ethnodrama. Saldaña (2018) cautioned any researcher attempting to use ethnodrama who is not versed in theatre or drama conventions, that their script could easily fall short of the goals of the genre. The researcher should then seek collaboration with those possessing the knowledge for dramatic representation and combine their 
expertise. The goals for ethnodrama, then, include creating social change, giving voice to silent voices in society, and creating understanding and empathy between the participants and the audience in order to become a catalyst for change (Prentki \& Pammenter, 2014; Saldaña, 2018).

\section{William Doll's 4Rs}

Rhoades (2018) drew a connection to complexity theory with William Doll's (2013) 4Rs, Richness, Rigor, Recursion, and Relations, to frame an understanding of ethnodrama. The 4Rs not only help frame ethnodrama as a methodology but also the applied drama projects used in this study. Richness "refers to a curriculum's depth, to its layers of meaning, to its multiple possibilities or interpretations" (Doll, 2013, p. 254). In ethnodrama, the wide range of personal participant perspectives, texts, and stories provides a rich base of data to work from. Like a curriculum, a script needs to have depth and breadth to provide a rich experience for the audience. Researchers also draw on the existing literature and sometimes autoethnography to build the script.

Rigor is key to analysing and interpreting the data into a script for performance. Doll (2013) defines rigor as a conscious effort to uncover assumptions with a combination of indeterminacy with interpretation. The interpretation of the data in ethnodrama includes the author's assumptions and bias as well as the assumptions of the participants and the audience. The understanding of the play will differ between audience members. The goal is not to present one truth but to present a truth with multiple interpretations.

Relations are valued between the participants' experiences, the actors' interpretations, and the audience's understandings of what they have experienced. Ethnodrama is a call for action. It invites participants and audiences to engage with topics presented in the scripts in a reflective manner, and encourages participants to make personal connections and the unveil oppressions (Mahotra \& Hotton, 2018; Rhoades, 2018). This multidimensional truth can assist in improving the script through feedback and dialogue. This Recursion occurs earlier in the process of ethnodrama between the researcher and the participants and then again when an audience is included.

\section{Data Generation}

For this study, I generated data during unstructured interviews with four former students who participated in The French Play in both 2016 and 2018. The participants were teens, so I conducted the interviews in pairs to give more comfort to them and to allow for more natural dialogue about their experiences. Two of the teens were siblings that participated in different years of The French Play and two were friends who had co-written their original scene. I obtained signed ethical consent from both the students and their parents. The students chose to use their own names in the research. The script excerpts and video clips from the original French Plays used in the research were those written and performed only by the participants and were not shared publicly.

My questions were intended to gain an initial broad understanding of the phenomenon of participation in applied theatre: What were your experiences of participating in an applied theatre production as a learning experience and as a process to better understand social justice issues in society? What do you feel is important for teachers to know if they are trying to use applied theatre as a tool for teaching and learning? 
According to Sparkes and Smith (2014), the unstructured interview can allow the researcher to explore a broader topic and can spark spontaneous stories, ideas, understandings of reality (p. 85). I provided photos to both pairs of participants from their own past shows and copies of their original scripts. Due to new COVID-19 restrictions during the interview period, one pair had the opportunity to walk around the theatre and take their own photos in order to encourage talk. The second pair was interviewed over Zoom. These artefacts combined with both researcher and participant generated photo-elicitation "ha[d] the multiple benefits of helping people to remember key events and assist them in reliving their experiences" (Sparkes \& Smith, 2014 , p. 98). The participants were asked to share what they remembered and what they thought was important for others to know about the applied theatre experience. I provided photos of themselves in the original plays and they chose sites such as the Green Room in the theatre for me to photograph. This approach to data generation provided a rich base of information especially with the pair that had the opportunity to be in the theatre. The participants who had the opportunity to revisit the theatre spoke longer on the topic and shared more stories than the pair that viewed past photos of themselves in The French Play and conducted the interview via Zoom. Although the research project was adapted to what was possible rather than what was ideal, the richness of the response showed that the adaptation did not appear to reduce the meaning-making process for the participants.

\section{Data Analysis}

I used narrative analysis to find themes in the interview transcripts. Narrative analysis takes stories as a source of data. Stories are a complex interweaving of our pasts, our relationships and the contexts in which we are situated (Vieira, 2014). As noted by Sparkes and Smith (2014), "Narrative analysis fits well with ethnodrama because it reveals a great deal about the sociocultural fabric of lives, subjectivity, feelings, agency, and the multi-layered nature of human experience" (p. 130). I generated the transcripts from the video recordings of the stories shared during the unstructured interviews using YouTube auto-transcription (Hopper et al., 2021). I cleaned up the transcripts and added names to identify the speakers; however, I chose to leave the spacing as it was created. The spacing that naturally occurred in the auto-transcription process mirrored the nature pauses and breaks in each person's speech patterns. Because I planned to use verbatim extracts for the eventual script, I wanted the transcript to not only reflect participant words but also ways of speaking that differed between participants.

I followed Sparkes and Smith's (2014) outline of steps to do this type of analysis: first, writing initial thoughts, then identifying key themes, then tracking within a narrative, then making conceptual comments, next naming the theme and writing the script/story, then comparing and contrasting the two sets of interviews, and finally, writing the report (script). As I read the transcripts, I noticed that Doll's 4Rs (2013) were emerging as key process themes. The participants were describing the experience of working through the drama in the theatre project and I had noticed significant similarities between applied theatre and ethnodrama as a research tool during my initial readings. I began with recursion, relations, rigor, and richness as initial organizing themes to test the similarities I was noticing between ethnodrama and applied theatre in my initial readings in the literature.

From these initial themes, I added sub-themes that better described the theme in the context of the data. I noticed that whenever I had coded Rigor as a theme, it was centered on portraying sensitive topics. The participants spoke about the continual conscious effort to portray 
a story truthfully but also respectfully. "In dealing with indeterminacy, one can never be certain one 'as it right.' ... One must continually be exploring, looking for new combinations, interpretations, patterns" (Doll, 2013, p. 259). Participants described the indeterminacy inherent in anticipating the audience reaction with how to best stage a sensitive scene such as a teen suicide or how to use authentic language that may be offensive in their scenes.

I broke the Relations theme into three sub-themes after the initial coding: The interpersonal relations in co-creation of text between the student participants, the participant/actors with the audience, and the relationship with the self through emerging confidence and self-awareness. Recursion emerged as a dominant theme as the script and staging were being adjusted throughout the writing, staging, and performance aspects of the applied learning project. Richness was apparent in the script development as the participants described the "layers of meaning, [the] multiple possibilities or interpretations" (Doll, 2013, p. 254) that were possible with each decision. I added a theme of conscientization as I read the transcripts and as the ideas of praxis - reflection and action-either fit in multiple areas of Doll's 4Rs or in none.

Once the text was coded into the themes and sub-themes, I copied them into a table so that I could see the interviews side-by-side by theme. I then used a combination of three of Saldaña's (2018) outlined methods of generating scripts for ethnodrama: adaption of interview transcripts, adaptation of nonfiction texts and devised work through improvisation. I also used two more methods that fit this particular research study: previous script excerpts and researcher voice.

\section{Adaptation of Interview Transcript}

I used verbatim excerpts of transcripts, cleaned up and adapted to create a script (Nimmon, 2007). When cleaning up the transcripts, I was unsure as to whether I should take out the use of "yeah" and "like" that were repeated throughout the interviews. Their inclusion made the voices of teenagers sound more authentic but at times made it difficult to follow. I asked the participants before we recorded the script if I had made the correct choice. They all agreed that they preferred that I had taken out the majority of these voiceprints as the result was a clearer, more "professional" version of their opinions.

As I highlighted in the script the few lines I had added to create transitions between scenes so that the participants could see what was or was not their original words. As I pulled verbatim extracts, I highlighted them in my coded text tables so that I could keep track of what I did and did not use for the script. In ethnodrama, “you don't compose what your participants tell you in interviews, but you can creatively and strategically edit the transcripts, assuming you wish to maintain rather than 'restory' their narratives" (Saldaña, 2003, p. 223).

\section{Previous Script Excerpts}

I also pulled scenes from the original two scripts written by the students when they were in Grade 8 as they fit with the themes that emerged. I left these scenes in their original French and, as part of the research performance, they were played as video clips from the past performances of the student plays rather than read aloud. The past scripts and video clips were ones the research participants had written and performed initially. I did not use scripts from students who were not participating in the research project. The ethnodrama, a panel of experts 
in discussion, was performed via video conference due to COVID-19 pandemic protocols that prohibited theatre gatherings or live audiences.

\section{Devised Work Through Improvisation}

When we performed the first draft of the script via video conference, participants were encouraged to add new lines, change their original lines, and create their own stage directions for their characters as we recorded. The stage directions and additional or changed lines were added to the script after this first "performance" via video conference from the recording.

\section{Adaptation of Nonfiction Texts}

Like Nimmon (2007), I built in knowledge from existing research in or around the participants' words through the voices of Saldaña and Freire as characters in the script. In the video run of the script, participants "changed hats" to play these two characters as well as themselves. Nimmon (2007) added the voice of the theorist in her ethnodrama on immigrant experiences of healthcare in Canada. In Nimmon's ethnodrama, she finished each scene as a separate voice to connect the scene with the existing literature. Similar to Malhotra and Hotton's (2018) addition of research into the dialogue of the characters in their ethnodrama, I also added quotes into the Studio Host character's script to add more of the literature to the script. I added these when I felt that a key finding was emerging from the participant voices. I chose to include the existing research through the characters of Freire and Saldaña as well as through the character of Studio Host to share the literature in a more aesthetic and engaging way than through conventional academic prose. Saldaña (2011) discouraged the addition of research in a script or dialogue but made the conscious choice to add this to the script. As the ethnodrama was written as a panel discussion, I wished to have Freire and Saldaña on that panel as characters for creative purposes. Similar to research-creation models outlined by Loveless (2019), I chose to push the limits of both traditional and artistic outputs by interweaving the fictional setting and characters and participant verbatim dialogue with the existing literature.

\section{Researcher Voice}

Because as a researcher I had also been the teacher for my student-participants at the time of the French Plays, I situated myself in the research as a participant-observer. This role had advantages because rapport and trust were already established with the participants, and it reduced the amount of time needed to complete the research steps as I was already familiar with the process we had followed to write the original plays. I was mindful throughout though to allow the participants to share their stories without my actively valuing or over-contributing to the conversation. I was transparent with the participants about wanting their honest opinions even if they perceived them as negative towards the process we had followed during the applied theatre projects. I told them that I was looking for ways to improve the program as well as honest feedback as an educator. When I wrote the script, I wrote myself in as the Studio Host character and kept all participant lines of dialogue true to the original interview transcripts.

After writing the script, I sent it to the participants for feedback and changes. Participants had 5 days to read and make suggestions or changes before our first performance. During our live video-conferencing Session 2, participants put on a different hat, literally, to show the characters of Freire and Saldaña in contrast to when they were playing themselves in the script. Due to these restrictions, I wrote the script as a fictional webcast on the topic of applied theatre 
with the four participants as the panel of experts and Freire and Saldaña as guest experts. As the researcher, I played the role of the Studio Host in the performance. I offered the role to the participants to play but they all felt that it needed to be my voice in the conversation. I called the Studio Host "Sheila" because I wrote it with the tone of Sheila Rogers who I have heard interview multiple panels over the years. The errors in the reading added a less stilted flow and some humor. The actor playing Freire stumbled on the word conscientization and improvised to recover which improved the final version of the script.

\section{Script Excerpt With Post-Performance Additions: Introducing the Panel of Experts ${ }^{1}$}

\section{SALDAÑA (donning Saldaña hat)}

Pleased as well. ... Will we be moving on soon? As "theatre's primary goal is to entertain ... [both] ideas ... as it entertains spectators" (Saldaña, 2018, p. 664), this introduction has the danger of becoming (looks directly at camera) stilted (pauses for effect) and forcibly academic in tone.

ASA (Smiling and shaking head)

Oh, I hate stilted dialogue ... STUDIO HOST (Smiling indulgently)

Hopefully the recursive nature of this approach will correct that as we move along ... Our theme for today's episode is Co-creation of script in an Educational ethnodrama or applied theatre. Mr. Saldaña, can you give us an introduction to ethnodrama as a research tool to 'set the stage' (air quotations) for all our listeners and viewers out there?

SALDAÑA (Smiling indulgently at the camera. Refined voice well-articulated)

Gladly, Sheila ... In ethnodrama, knowledge and truth are co-constructed and come from lived experiences. There is not one universal truth but instead multiple individual truths. You collect data and transform it into scripts using the words of the participants in combination with the words of the researcher and the existing body of knowledge.

\section{FREIRE (madly dons hat)}

This knowledge is catalytic for conscien ... conscienti ... conscientization! (pauses trying not to laugh) I know that word because I am a scholar ... The researcher not only wants to share insights on the human condition but also be a catalyst for social change. Conscientious ... (awkwardly long pause) Con-sci-en-tia-za implies that an action is taken beyond simple awareness of the issue! Praxis! Reflection and action!

\section{SALDAÑA}

"In well-written ethnodrama, scholarly discourse is pushed aside to communicate both the everyday and the exceptional through more authentic and accessible language" (Saldaña 2018, p. 664). 


\section{CHARLOTTE}

Your explanations were very ... er ... accessible ...

OLIVIA

No scholarly discourse there. ...

\section{STUDIO HOST}

Very ... illuminating ... and Freire, I know that you actually did not want that word translated into English you prefer it in its native Portuguese which is why I feel you stumbled over this evening because you made quite a point that it should never be translated!

FREIRE (quickly puts back on FREIRE hat and nodding sagely and gesturing with both hands spread to the audience)

Of course.

STUDIO HOST (enumerating steps on right hand)

So ... Collect data and write a script and perform it in an effort to change society $\cdots$

\section{SALDAÑA (Quickly donning hat for Saldaña-Grandiose voice)}

You must perform it well though! "Boring theatre (looks up and shakes head sadly) is bad theatre!" (Saldaña, 2018, p. 664).

Which raises the question as to why we are on Zoom ... where are the costumes? The staging?

\section{STUDIO HOST (Radio voice)}

Global pandemic, Johnny.

\section{Findings}

My criteria included both creating interesting scenes in the ethnodrama and attempting to represent reliable information by drawing most heavily on repeated or frequent themes and ideas in the transcripts. Goldstein (2017) reminded that "research-informed theater practitioners must find a way to negotiate conflicting commitments to veracity, authenticity, and theatricality ( $\mathrm{p}$. 443). Outlined in what follows, five key findings emerged.

\section{Richness and Problem-Posing Education-The Process of Co-creating Scripts Based on Student Voice and Choice}

All of the participants talked about the allowance they had been given when they were Grade 8 students to tell any story and to work with whomever they chose to connect to their chosen topic from a prompt or time period, and to build both their confidence in, and their relationships with, peers. Some chose to write alone so that they could have full creative control over their scene before adding it to the greater narrative and others wrote as a group. Asa, Charlotte, and Hazel worked on the play Le tyran (The Bully) in 2018. The premise the students 
decided upon was a high school bully trapped in a gym being visited by ghosts of bullied past students over 100 years. Each student or group of students chose a reason that students were bullied to write their scene. Asa and Charlotte wrote about homophobia. This came out of a mutual desire to address this issue as well as mutual trust as friends and co-writers. Hazel wrote about misogyny in the education system. Other themes that arose were racism, classism, slut shaming, and poverty. Olivia contributed to Le gobelet d'or (The Golden Goblet) in 2016, a story about a time traveling archeologist who learned that equality and social justice are more important than fame and fortune. Olivia co-wrote a scene that showed the contributing factors to the French Revolution.

The participants talked about the importance of working collaboratively as a class to weave the individual scenes into a story that they wanted to tell without the "meddling" of a teacher. This finding from the research supports Freire's (2000) criteria for problem-posing education:

The teacher's thinking is only authenticated by the authenticity of the students' thinking. The teacher cannot think for her students nor can she impose her thoughts on them. Authentic thinking, thinking that is concerned about reality, does not take place in ivory tower isolation, but in communication. (p. 77)

The communication skills the students built as partners, groups, and then as a class allowed them to write stories that they reported were important and authentic.

\section{Script Excerpt: Making a Connection}

\section{CHARLOTTE}

Originally I think I was going to be with Jane and then she was like, "I'm off to work with someone else ..." and I was like ... (sarcastic little kid voice) "okay." When I realized that I was going to be with you, (laughing conspiratorially) I remember being like ... oh good. (Asa gestures as, oh me?)

\section{[laughter]}

ASA

I remember when we were thinking about the ideas that we had and I think I raised my hand and was like ... uh ... homophobia? You were like, (gestures in air with fist) "yes!" I remember you were on the other side of the room and I thought ... I hope I'm with Charlotte.

\section{CHARLOTTE}

I really enjoyed 1 being able to write with someone who I was confident ... (looking up thinking) was going to be ... really ... good ... (nodding) at ... what we were doing ... (smiles knowingly at Asa)

Hazel and Olivia nod in agreement with the statement.

ASA 
You have to trust the kids. They'll have their own ideas because kids have a lot of wisdom even if when they say it, it comes out ... childish. If you listen to what they're actually trying to say .... you might find that it's real and impactful. ... and it means a lot to them.

\section{Rigor and Recursion-How to Write and Represent Sensitive Topics on Stage}

One of the challenges of using ethnodrama is the responsibility of respectfully and authentically constructing the script (Goldstein, 2017). The personal and sometimes traumatic nature of lived experiences has to also be at the forefront of the researcher's mind so that dialogue and continued co-construction is not damaging to the participants or the audience. There should be an effort to predict any ethical or moral dilemmas and any triggers for the potential audience. In an effort to remain true to the data, the risk may be "unforeseen emotional responses to the performance" (Sparkes \& Smith, p. 169).

This is a similar concern when using applied theatre as an agent for change. The second finding from this research was the importance of rigor and recursion to properly tell stories that have sensitive and possibly triggering effects on the audience in applied theatre. The audience of The French Plays were middle school students aged 11-13. The students made some very bold choices but expressed that their belonging to the silenced or oppressed community in question helped to give them courage to tackle the topic in a more authentic way. The recursive process of workshopping scenes and rewriting/restaging was equally important to the participants in applied theatre as it is in ethnodrama as a research tool. The students rehearsed the scenes they had written and then rewrote and restaged each one until they felt it was ready for their audience. The scene in Le tyran about teen suicide was very short on paper but required the most discussion, reflection, and adjustment on stage until the participants felt that it honored the seriousness of the topic but still conveyed its central emotions to the audience without triggering trauma or a negative reaction in the audience. The choice to include a slur in the scene about homophobia in Le tyran was also the product of extensive dialogue and reflection. They wanted to tell the story well but they also wanted to be honest about what they were hearing in the middle school context.

\section{Script Excerpt: The Swear Word}

STUDIO HOST

Whoa ... um. Cut. This is a play for middle school .... Is that language ... um ...

\section{CHARLOTTE}

We ... we both decided that we felt okay about it ...

ASA

We had a long ... think ... about that ...

\section{CHARLOTTE}

There was a big discussion about using that word. ... 
ASA

I felt like personally better about it in French ... in English, I'd definitely have more qualms about it!

\section{CHARLOTTE}

Steer away from it for sure ... but in French? I remember when you brought up that idea we were like ... okay ... let's talk about this. ... (laughing)

ASA

Yeah, yeah, like should we do this?

\section{CHARLOTTE}

I remember watching the script get so long sitting at my computer in my room you'd added little notes right next to the "bad word" ... like "heehee" this is a bad word... ASA

Okay, in my defense, I swore a lot more then but I didn't know you well enough that I knew I would be able to swear around you ...

\section{CHARLOTTE}

Yeah, (voice goes higher and cutesy) it was so cute. (Back to regular speaking voice) But seriously though, we made sure that we felt okay about who was saying it as well.

ASA

It was good that we were both queer because-

\section{CHARLOTTE}

— because being a part of that community made it feel safer.

\section{STUDIO HOST}

What if you make someone feel uncomfortable ... I mean ... If you weren't even sure that Charlotte would be ok with it ...

ASA

Isn't that kind of the goal? (sighs) I love Social Justice Theatre ....

\section{Conscientization: The Power of Theatre to Create Change}

Another important finding reported by participants was the importance of theatre as opposed to assemblies, books, or presentations to create social justice change especially for youth. All of the participants talked about the power that drama has to connect emotionally with an audience and create empathy for oppressed voices. They all spoke about situations they experienced during and after performances of audience reactions and shifts in understanding. 


\section{Script Excerpt: Toying With Emotions}

\section{CHARLOTTE}

I had a lot of fun doing this because I felt good about what we were performing.

ASA (relief/quietly emphatically)

Same.

\section{CHARLOTTE}

I felt proud and that we were helping even in a small way to make a difference to the people watching. Sharing people's experiences with these issues can help change people's points of view because you can hear something a million times but not actually see it, you know?

ASA

I also agree with that. I mean part of me was worried that somebody was gonna like yell something homophobic from the audience ... (finishing each other's sentences) CHARLOTTE (smiling awkwardly)

or laugh ...

ASA

... or laugh. (sigh) Honestly, I was worried about that.

\section{STUDIO HOST}

"There is the potential for folks to develop empathy and to connect with vulnerability - the vulnerability of others, and our own - while providing empowerment to those who have been silenced." (Malhotra, 2018, p. 158) It sounds like you all really connected during this process ...

\section{CHARLOTTE}

Just knowing that our script and the way we performed - the fact that it actually really impacted people's ... is important. Our other teacher, who came up afterwards and had and told us that he had cried. I was like, "I'm sorry that we made you cry" ... but at the same time that's kind of good because that's sort of what we were going forthat connection. For the audience to the point of feeling emotion themselves towards the characters and their situations is something that people strive for in theater... . Yeah ... like toy with your emotions ...

\section{ASA (enthusiastically interjecting)}

Oh it's so fun! It's one of my favorite parts of theater because I really like that there's so many facets that can really come together to create like an emotional impact. (finishing each other's sentences again)

CHARLOTTE (conspiratorial) 
A nice cocktail of emotions ...

ASA

So nice ... I love that!

\section{SALDAÑA (donning Saldaña's hat)}

I also love it! As I've said before to my public, "Stop thinking like a social scientist and start thinking like an artist!" (Saldaña, 2018, p. 686)

\section{CHARLOTTE}

I remember one of my favorite things that I got told from the point of view of someone

watching our scene was Hazel informing us...

ASA (making two fists enthusiastically interrupting)

Oh my god, yes! Yes! Oh my god I loved it so much ... it made me so happy! Sorry, I totally interrupted you, yeah ... continue ...

\section{CHARLOTTE}

There was a boy in the audience in the front row ...

ASA

Was it one or two?

\section{CHARLOTTE}

I think there were two and they were joking with each other during our scene when we first come on being like - oh look at these guys-you know? and like kind of just not taking it that seriously and Hazel had been of course watching our scene and she informed us of this afterwards. About halfway through our scene, when ... when things started to escalate, and Vincent had his rage coming out, and then they had this moment together ... both boys' expressions changed and they went from like mocking it to genuinely watching the scene and being interested. I really hope that that stayed with them. Especially in middle school ... for whatever reason ... a lot of people joke around about subjects that are more sensitive to many people and I hope that after watching they realized .... Even if you're told something, you don't necessarily get it ...

ASA

You're so far removed from it ... yeah ... You're just like—-gay people exist, cool.

\section{CHARLOTTE}

Good to know. 
ASA

Wonderful. But watching it ...

\section{CHARLOTTE}

Even if you're having a conversation with someone or with a group of people about a social issue, you might not get people listening or really paying attention. They'll hear you but they won't take it to heart but just the ability to stand on stage and perform and to give it in that sense of reality ... I think like as a society, people kind of know that if someone's acting or someone performing on the stage, then you listen ...

ASA (nodding)

It's their time.

\section{CHARLOTTE}

You watch and listen.

\section{Relations: The Importance of Adults Listening to the Voices of Teenagers}

A very clear message that emerged from this research from all of the participants is that the voices of teenagers are not always valued. They expressed the frustration that they not only have been weighted with the responsibility of fixing the current world by adults but also at the same time they are not always heard. According to the participants, the relationship between adults and teens needs to include listening on the part of adults.

\section{Script Excerpt: Save the World}

\section{CHARLOTTE}

Kids and teenagers in general, especially in our generation, have got this mindset now that's been given to us of, 'okay, yeah ... now we have to deal with all these things going on and fix them because it's currently up to us ... and yeah with help from other generations as well but ...

ASA

Yeah ... go save the world now ... um (raises eyebrows questioningly)

They reported that the process of applied theatre had given them an opportunity to make themselves not only heard but respected for their thoughts and ideas. Their message to adults was to trust in youth and to listen even when they aren't able yet to express themselves in a linear or cohesive way. They said that they can handle the responsibility of tackling serious issues if they are given the opportunity

\section{Script Excerpt: Sensitive Material ... in a Smart Way}

HAZEL

You know .... telling the story that has like this weight to it. I think that was really big for me. (smiling and nodding) It is good .... It makes Grade 8s think. 


\section{OLIVIA}

Especially this year ... It's such a heavy year. I mean people have probably have a lot of feelings and things that they want to talk about and there's so much happening ... You can always just use that for your stories and your theater. It's cool giving students an outlet - a creative outlet-is so cool.

\section{SALDAÑA (donning Saldaña's hat)}

"Ethnodrama provides opportunities for participants with marginalized 'offstage' status in everyday life to stand centre stage and tell their stories" (Saldaña, 2003, p. 67). This is important every year. We always have a story to tell. There are so many silenced voices.

\section{MACEDO (ranting)}

Marginalized? Oppressed. It is the "liberal educators [that] remain complicit in the erasure of language - an act that empties out, for example, the meaning of the term[s] 'oppressed' ... 'disenfranchised', 'economically marginalized', 'minority', and 'at-risk' among other[s] [that are used] to refer to the oppressed, but in doing so obfuscate the true historical conditions that explain the "here and now'!" (Macedo, as cited in Freire, 2000, pp. 17-18)

\section{STUDIO HOST}

Macedo ... I appreciate you wrote the introduction to Freire's 50th anniversary edition but I don't think you were invited to this script ...

\section{OLIVIA}

Um ... Thanks, Macedo ... It is important, I think, that we give kids a chance to talk about difficult topics. To talk about the ... "oppressed." Grade 8s are old enough to understand that they're dealing with sensitive material and ... they can do it in a smart way.

HAZEL (smiling at Olivia and nodding in agreement)

(softly) Yeah. They really are.

\section{OLIVIA}

It worked. It never felt awkward seeing them handling material like that. It just kind of felt like they'd put thought into it ...

\section{HAZEL}

I think because we were covering very serious topics, along the way we did a lot of read-throughs from the very beginning, which I think was really good because you kind of grew the space so it was comfortable to be in. It's really scary getting up in front of your classmates. By doing that, you have the people who you're performing with being really confident with each other. 


\section{CHARLOTTE}

Yeah ... we poured our souls into Le tyran, to make it what it was. But I had worries about certain kids in the class because I had had slightly negative experiences with jokes and comments about certain issues like homophobia and misogyny that we dealt with in this play, but by the end of it, I noticed that everyone knew the severity of the issues.

\section{OLIVIA}

I think it's sort of like having a lot of faith that the kids, at the end of the day, do want to put on a show that they're proud of and then therefore will do the work. The amazing thing about theater is that you have this amazing result at the end of seeing your work paying off and seeing people's reactions to your work unlike doing a math sheet ... where, you're like ... great! I got a good grade ... Theater actually pushes me to do something like the hardest work ever done.

FREIRE (donning the Freire hat)

Ah, yes, the worksheet ... the test ... the banking model of education ... Teachers are the depositors and students are the depositories - ready to receive, memorize and repeat .... (Freire, 2000, p. 72)

\section{OLIVIA (interrupting)}

Well ... you do have to memorize and repeat in theatre ...

\section{Relations: The Personal Impact on the Participants' Self-Development}

One of my original research questions was to investigate the impact on the participants more specifically in social justice understandings and conscientization but there was also personal development that occurred for all the participants. Gallagher and Mealy (2018) proposed that

any theory of self-creation for young performers/cultural producers should be understood as embedded in relationships; that the artistically discovered possible selves are authorized and critically supported by a community of self-searchers, willing to take risks, experiment, succeed and fail, together. (p. 150)

I found that the process had a significant impact on participants' confidence and interpersonal skills. They reported that they also learned to make better connections with peers and to work collaboratively towards a common goal. All four participants have continued working in theatre since their experience in Grade 8 as both actors and writers.

\section{Script Excerpt: Confidence to Address Things Head-On Because of Comfort With Each Other}

\section{OLIVIA}

You do get really comfortable as a class when you're getting up on stage and performing for each other or doing a scene with them. Everyone becomes close and good friends, I would say. You're spending so much time together. You're doing important but also kind of challenging work with them which then leads to bonds forming. The unity of 
the creative experience kind of works out to form really nice friendships along the way which you don't get in a classic classroom setting of like- desk work.

\section{HAZEL}

I just found that you got very comfortable with the people around you and you were able to address things more head-on because .... because of that comfort - which I thought was really good. (nodding) I really got a lot more confident. (nods and smiles at the camera)

\section{OLIVIA}

I would say it really helped me with coming out of my shell a little bit in terms of like ... seeing myself as a leader. I had probably more experience with what we were doing than a lot of other people. I sort of had to come to terms with the fact that I could actually use this to be helpful. Giving kids opportunities to feel that way is amazing! Letting them explore what they are passionate about from a young age and share it with other people.

\section{Conclusion}

Ethnodrama as a research tool and applied theatre have similar impacts on helping audiences to develop a better understanding of the world and to make change based on those reflections. Researchers choosing ethnodrama to represent their data and findings are committed to telling the stories of their participants as accurately and authentically as possible and to use that data as a catalyst for social change. The participants' words, dialects, and ways of speaking are conserved as much as possible in an attempt to create verisimilitude. The audience knows that the stories are lived experiences and not a fictional construction of the researcher to problematize or idealize a situation. This authenticity gives ethnodrama more power to achieve its goals of creating empathy, calling the audience to question their own privileges and beliefs, and taking action. The participants echoed this in their experiences in The French Play. They felt they had a space to tell authentic stories in their own words and to learn how to work collaboratively in a respectful manner. The audiences for the Grade 8 performances, both adult and peer, gave positive and supportive feedback to the actors that empowered the participants to continue in theatre as a tool for social change. The process was driven by the students/participants and the ideas that became scenes in the script were derived from the stories they felt important to tell. A teacher of applied theatre, like a researcher using ethnodrama, needs to build in space for voice and recursion. Through the recurrent process of reworking and revising the script and the performance, students benefited more than if the content and staging had been teacher driven. Participants all voiced that this was key to their experiences in The French Play. Some of the stories the students chose to tell were sensitive in nature and much thought was put into how to stage them without triggering audiences in a negative way. Teacher guidance and checking is key to monitoring these potential unintended consequences to social justice theatre but they must "practice co-intentional education. Teachers and students (leadership and people), co-intent on reality, are both subjects, not only to the task of unveiling that reality, and thereby getting to know it critically, in the task of recreating that knowledge (Freire, 2000, p. 69).

Another challenge of this genre is theatrical quality. If the researcher is not versed in theatre writing and production, the script can become stilted and lack realism (Saldaña, 2018). 
As a teacher, I have 20 years of working in drama education, both with writing scripts and producing other dramaturges' plays. This experience made the process of adapting the transcripts into scripts easier. The participants in this study had also co-written scripts with me during their French Play experiences and were comfortable with the role of co-writer and contributor. It is important for researchers using ethnodrama or any research-informed theatre to find ways to present both authentic and accurate information and create an engaging piece of theatre (Goldstein, 2012/2017). Unlike genres that are designed for print, ethnodrama should be more than words on the page divided between characters. The script and audience viewing needs to include the aspects of theatre that make it an aesthetic experience such as staging, costuming, and action. This sense of action and storytelling should also be apparent in the text script with actor cues, stage directions, and character descriptions. This was a limitation in my study due to COVID-19 pandemic restrictions on gatherings and theatrical presentations. I wrote the script to be presented via video conference but I was concerned that some of the impact, which can only be experienced with a live audience, would be lost. The technical difficulties and awkwardness of any meeting or drama in this online format actually added to the script as I had written it. Video failures, wifi connectivity, and uncertainty of where to look added not only humor but also a new age of verisimilitude to this ethnodramatic production. Everyone who was living in 2020 will find a sense of connection with this theatrical endeavor. As they say, the show must go on! 


\section{References}

Belliveau, G., \& Lea G. W. (2011). Research-based theatre in education. In S. Schonmann (Ed.), Key concepts in theatre/drama education. Sense Publishers. https://doi.org/10.1007/97894-6091-332-7_54

Boal, A. (1993) Theatre of the oppressed. (C. A. McBride \& M-O. L. McBride, Trans.). Theatre Communications Group. (Original work published in 1985).

Conroy, C., Dickenson, S. J., \& Mazzoni, G. (2018). The 'not knowns': Memory, narrative and applied theatre. Research in Drama Education: The Journal of Applied Theatre and Performance, 23(1). 56-72. https://doi.org/10.1080/13569783.2017.1398641

Denzin, N. K., \& Lincoln, Y. S. (2018). The SAGE handbook of qualitative research (5th ed.). SAGE.

Doll, W. (2013) The four R's_-An alternative to the Tyler rationale. In: D. J. Flinders \& S. J. Thornton (Eds.), Curriculum studies reader (4th ed., pp. 215-222). Routledge Falmer.

Freire, P. (2000). Pedagogy of the oppressed (50th anniversary ed.). Bloomsbury Publishing.

Gallagher K., \& Mealey S. (2018). Staging our selves: Towards a theory of relationality, possibility, and creative youth selfhood. In S. Burgoyne (Ed.), Creativity in theatre. Creativity theory and action in education (vol. 2.). Springer. https://doi.org/10.1007/9783-319-78928-6

Goldstein, T. (2012). Staging Harriet's house: Writing and producing research-informed theatre. Peter Lang.

Goldstein, T. (2017). Veracity in Alana Valentine's Ladies Day: Implications for researchinformed theater. Qualitative Inquiry, 23(6), 438-444.

https://doi.org/10.1177/1077800416673661

Hopper, T. F., Hong, F., Sanford, K., \& Alonso Hinkel, T. (2021). YouTube for transcribing and Google drive for collaborative coding: Cost-effective tools for collecting and analyzing interview data. The Qualitative Report, 25(3). https://doi.org/10.46743/2160$3715 / 2021.4639$

Loveless, N. (2019). How to make art at the end of the world-A manifesto for research creation. Duke University Press.

Malhotra, N., \& Hotton, V. (2018). Contemplating positionalities: An ethnodrama. The Journal of General Education, 67(1), 152-171. https://doi.org/10.5325/jgeneeduc.67.1-2.0152

Mienczakowski, J. (2019). Ethnodrama and ethnofiction. In P. Atkinson, S. Delamont, A. Cernat, J. W. Sakshaug, \& R. A. Williams (Eds.), SAGE research methods foundations. https://www.doi.org/10.4135/9781526421036745330

Nimmon, L. E. (2007). ESL-speaking immigrant women's disillusions: Voices of health care in Canada: An ethnodrama. Health Care for Women International, 28(4), 381-396. https://psycnet.apa.org/doi/10.1080/07399330601180016 
O'Connor, P., \& Anderson, M. (2015). Research: Radical departures. Applied theatre.

Bloomsbury Methuen Drama. http://dx.doi.org/10.5040/9781472513489

O'Connor, P. \& O'Connor, B. (2009). Editorial. Research in Drama Education: The Journal of Applied Theatre and Performance, 14(4), 471-477. https://doi.org/10.1080/13569780903285966

Prentki,T., \& Pammenter, D. (2014). Living beyond our means, meaning beyond our lives: Theatre as education for change. Applied Theatre Research, 2(1), 7-19. http://dx.doi.org/10.1386/atr.2.1.7_1.

Rhoades, R. (2018). Intersectionality and solidarity in curriculum-making theatre encounters with marginalized youth researcher-artists. Journal of the Canadian Association for Curriculum Studies, 16(1), 185-198. https://jcacs.journals.yorku.ca/index.php/jcacs/article/view/40358

Saldaña, J. (2003). Dramatizing Data: A Primer. Qualitative Inquiry, 9(2), 218-236. https://doi.org/10.1177/1077800402250932

Saldaña, J. (2011). Ethnotheatre: Research from page to stage. Left Coast Press.

Saldaña, J. (2018). Ethnodrama and ethnotheatre: Research as performance. In N. K. Denzin \& Y. S. Lincoln (Eds.), The SAGE handbook of qualitative research (5th ed., pp. 662-696). SAGE.

Sparkes, A., \& Smith, B. (2014). Qualitative research methods in sport, exercise and healthFrom process to product. Routledge.

Taylor, P. (2002). The applied theater: Building stronger communities. Youth Theatre Journal, 16(1), 88-95. https://doi.org/10.1080/08929092.2002.10012543

Vieira, R. (2014). Life stories, cultural métissage, and personal identities. SAGE Open, 4(1), 112. https://doi.org/10.1177/2158244013517241

Ward, A., with Balabuch, A., Frodsham, L., Jarvis, D., Larkin, T., Nahachewsky, C., O’Connor, K., Stokes-Bennett, D., \& Preece, A. (2017). "I wouldn't stand too close to this story if I were you ...”. In A. Burke, I. Johnston, \& A. Ward, (Eds.). Challenging stories: Canadian literature for social justice in the classroom. Canadian Scholars' Press.

\footnotetext{
${ }^{1}$ Stage directions are in italics and some dialogue is in bold— to reflect the actual performance.
} 